\title{
Cytoskeletal Protein Variants Driving Atrial Fibrillation: Potential Mechanisms of Action
}

\author{
Stan W. van Wijk ${ }^{+}$, Wei Su ${ }^{\dagger}$, Leonoor F. J. M. Wijdeveld $(\mathbb{C}$, Kennedy S. Ramos (1) and Bianca J. J. M. Brundel *(i)
}

check for updates

Citation: van Wijk, S.W.; Su, W.; Wijdeveld, L.F.J.M.; Ramos, K.S.; Brundel, B.J.J.M. Cytoskeletal Protein Variants Driving Atrial Fibrillation: Potential Mechanisms of Action. Cells 2022, 11, 416. https://doi.org/ $10.3390 /$ cells11030416

Academic Editors: Paolo Bernardi, Luca Scorrano and Gerardo Z. Lederkremer

Received: 10 December 2021 Accepted: 20 January 2022 Published: 25 January 2022 Publisher's Note: MDPI stays neutral with regard to jurisdictional claims in published maps and institutional affiliations.

Copyright: (C) 2022 by the authors. Licensee MDPI, Basel, Switzerland. This article is an open access article distributed under the terms and conditions of the Creative Commons Attribution (CC BY) license (https:/ / creativecommons.org/licenses/by/ $4.0 /)$.
Department of Physiology, Amsterdam Cardiovascular Sciences, Amsterdam University Medical Centers, Vrije Universiteit Amsterdam, 1081 HV Amsterdam, The Netherlands; s.w.vanwijk@amsterdamumc.nl (S.W.v.W.); w.su@amsterdamumc.nl (W.S.); 1.f.j.wijdeveld@amsterdamumc.nl (L.F.J.M.W.);

k.silvaramos@amsterdamumc.nl (K.S.R.)

* Correspondence: b.brundel@amsterdamumc.nl

+ These authors contributed equally to this work.

\begin{abstract}
The most common clinical tachyarrhythmia, atrial fibrillation (AF), is present in 1-2\% of the population. Although common risk factors, including hypertension, diabetes, and obesity, frequently underlie AF onset, it has been recognized that in $15 \%$ of the AF population, AF is familial. In these families, genome and exome sequencing techniques identified variants in the non-coding genome (i.e., variant regulatory elements), genes encoding ion channels, as well as genes encoding cytoskeletal (-associated) proteins. Cytoskeletal protein variants include variants in desmin, lamin $\mathrm{A} / \mathrm{C}$, titin, myosin heavy and light chain, junctophilin, nucleoporin, nesprin, and filamin $\mathrm{C}$. These cytoskeletal protein variants have a strong association with the development of cardiomyopathy. Interestingly, AF onset is often represented as the initial manifestation of cardiac disease, sometimes even preceding cardiomyopathy by several years. Although emerging research findings reveal cytoskeletal protein variants to disrupt the cardiomyocyte structure and trigger DNA damage, exploration of the pathophysiological mechanisms of genetic AF is still in its infancy. In this review, we provide an overview of cytoskeletal (-associated) gene variants that relate to genetic AF and highlight potential pathophysiological pathways that drive this arrhythmia.
\end{abstract}

Keywords: atrial fibrillation; genetics; cytoskeletal proteins; cardiomyocytes; DNA damage

\section{Introduction}

Atrial fibrillation (AF) is the most common age-related cardiac arrhythmia in Western society [1]. AF is characterized by irregular and often very fast contractions of the atrial cardiomyocytes, resulting in an irregular heart rate, palpitations, dizziness, shortness of breath, and tiredness in the patient. AF can occur when abnormal electrical impulses suddenly start firing in the atria and override the heart's natural pacemaker, which can no longer control the rhythm of the heart [1]. Importantly, AF is associated with severe complications, such as thromboembolic events, heart failure, cognitive impairment, and increased mortality [1]. Although in most cases, AF initially presents as short, self-terminating episodes, it often progresses into long-lasting episodes that are more difficult to reverse to sinus rhythm [1]. The progressive stages of AF are associated with structural changes that promote contractile dysfunction and the impairment of electrical conduction in the atrial myocardium [2-7]. Thus, the early detection of AF and the identification of patients at risk is of utmost importance in order to treat this arrhythmia and prevent its progression. Therefore, knowledge on the root causes of AF is essential.

Recent research investigated the potential root causes for AF. These include environmentallyinduced 'wear and tear' AF, congenital AF, and genetic AF [1]. 'Wear and tear' AF is associated with the sequela of aging as well as Western diet and lifestyle-related risk factors, such as hypertension, diabetes, obesity, and coronary artery diseases, as well as various non-cardiovascular diseases, including chronic kidney disease [1]. Furthermore, an estimated prevalence of $~ 5 \%$ 
of the patients with a congenital heart disease develop AF due to a combination of flaws in embryogenesis and peri- and post-operative factors related to correction of the heart defect [8]. This so-called congenital AF is characterized by AF onset at a younger age, and these patients often rapidly progress from persistent to permanent AF [9,10]. However, not all AF patients present with predisposing 'wear and tear' or congenital AF. In a subset of patients who account for approximately $15 \%$ of the $\mathrm{AF}$ patient population, $\mathrm{AF}$ is familial, suggesting a genetic predisposition (Figure 1) [11-14].

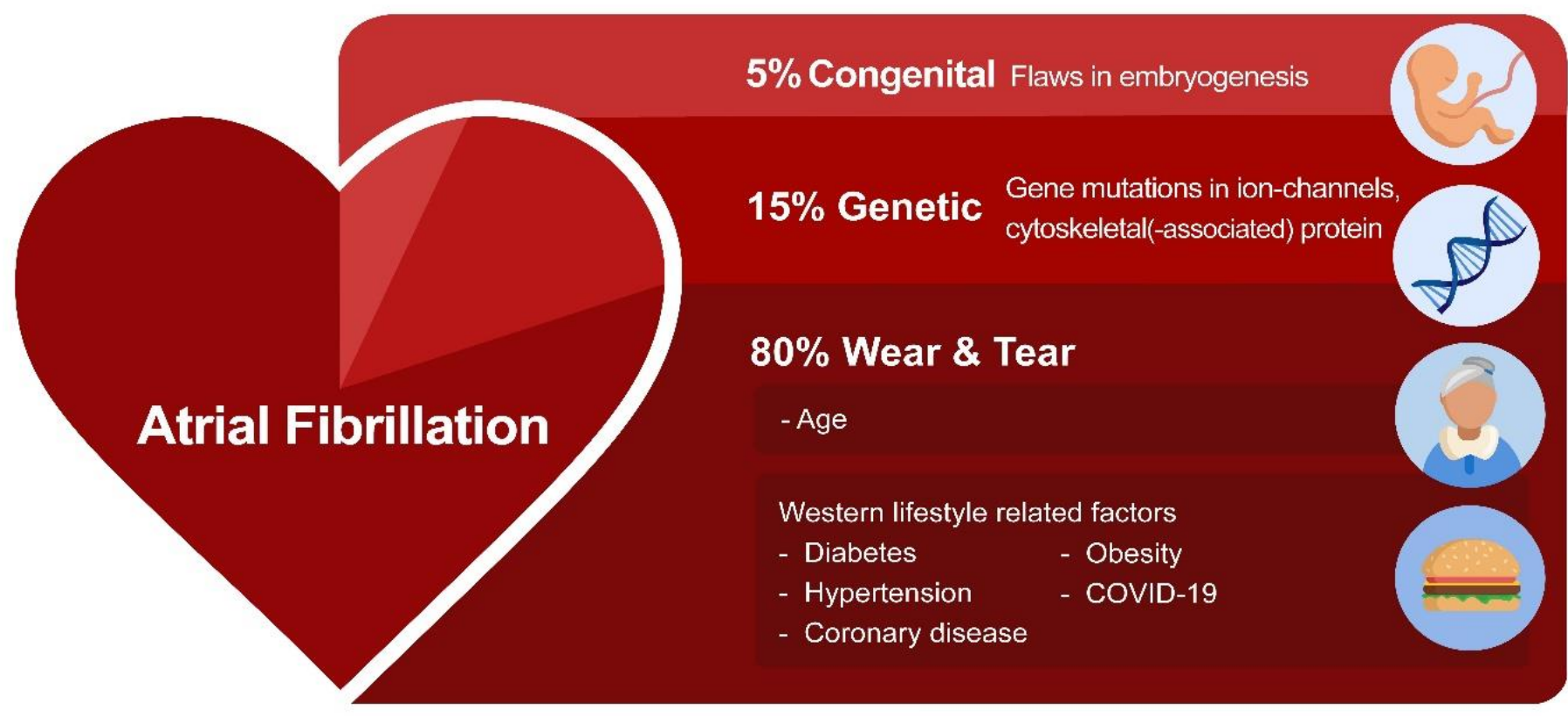

Figure 1. The variety of root causes that drive AF. In most AF patients, environmentally-induced 'wear and tear' related to aging or the Western lifestyle triggers AF. In addition, flaws in genetics (variants in ion channels and cytoskeletal proteins) and embryogenesis contribute to AF susceptibility.

Emerging research findings indicate a prominent role of genetic variations mainly in ion channel and cytoskeletal (-associated) genes in driving AF [15]. Although a research paper described the role of ion channel gene variants to underlie arrhythmias, including AF [16], insights into the role of cytoskeletal (-associated) protein variants as triggers for AF are in their infancy. In this review, we provide an overview of variants in cytoskeletal proteins associated with AF promotion and highlight potential pathophysiological pathways.

\section{Key Role of the Cytoskeletal Network in Cardiomyocyte Function}

It was only recently that the crucial importance of the cytoskeleton function to maintain balanced protein (i.e., proteostasis $[3,6,17,18]$ ) and cardiomyocyte function has been recognized. In cardiomyocytes, the cytoskeleton not only provides a communication highway by transporting proteins throughout the cell, but it also capacitates its contractile function [19-21]. In cardiomyocytes, the cytoskeleton is highly specialized, consisting of actin filaments, desmin (intermediate) filaments, and microtubules, interacting with membrane-associated proteins, sarcomeric and nuclear proteins, and proteins of the intercalated disk. This complex network, which also interacts with various organelles, including sarcoplasmic reticulum (SR), mitochondria, and the nucleus, plays an important role in the transmission of signals and the transport of (ubiquitinated) proteins within the proteostasis network $[6,19,22]$ (Figure 2). Within the proteostasis network, especially the microtubules are of vital importance. As the microtubules, SR/endoplasmic reticulum (ER), sarcomeres, and mitochondria are in contact with each other, loss in contact results in $\mathrm{Ca}^{2+}$ overload in the organelles, unfolded protein response in the ER, and, consequently, excessive autophagic protein degradation and mitochondrial dysfunction [5,6,23-25]. Contact 
between organelles and trafficking through the cells is mediated by acetylated microtubules $[3,6,26,27]$. Consequently, AF-induced histone deacetylase 6 (HDAC6) activation and the subsequent deacetylation and degradation of the microtubule network have detrimental effects on the trafficking of proteins as well as on the contractile function of the atrial cardiomyocytes $[3,28,29]$. Therefore, a functional cytoskeletal network underlies a balanced communication within the proteostasis network and ensures proper contractile function. The conservation of this network is of utmost importance to ensure proper cardiac function. As such, attenuation of the disruption of the cytoskeleton protects against cardiac diseases such as AF and heart failure $[3,26,30]$.

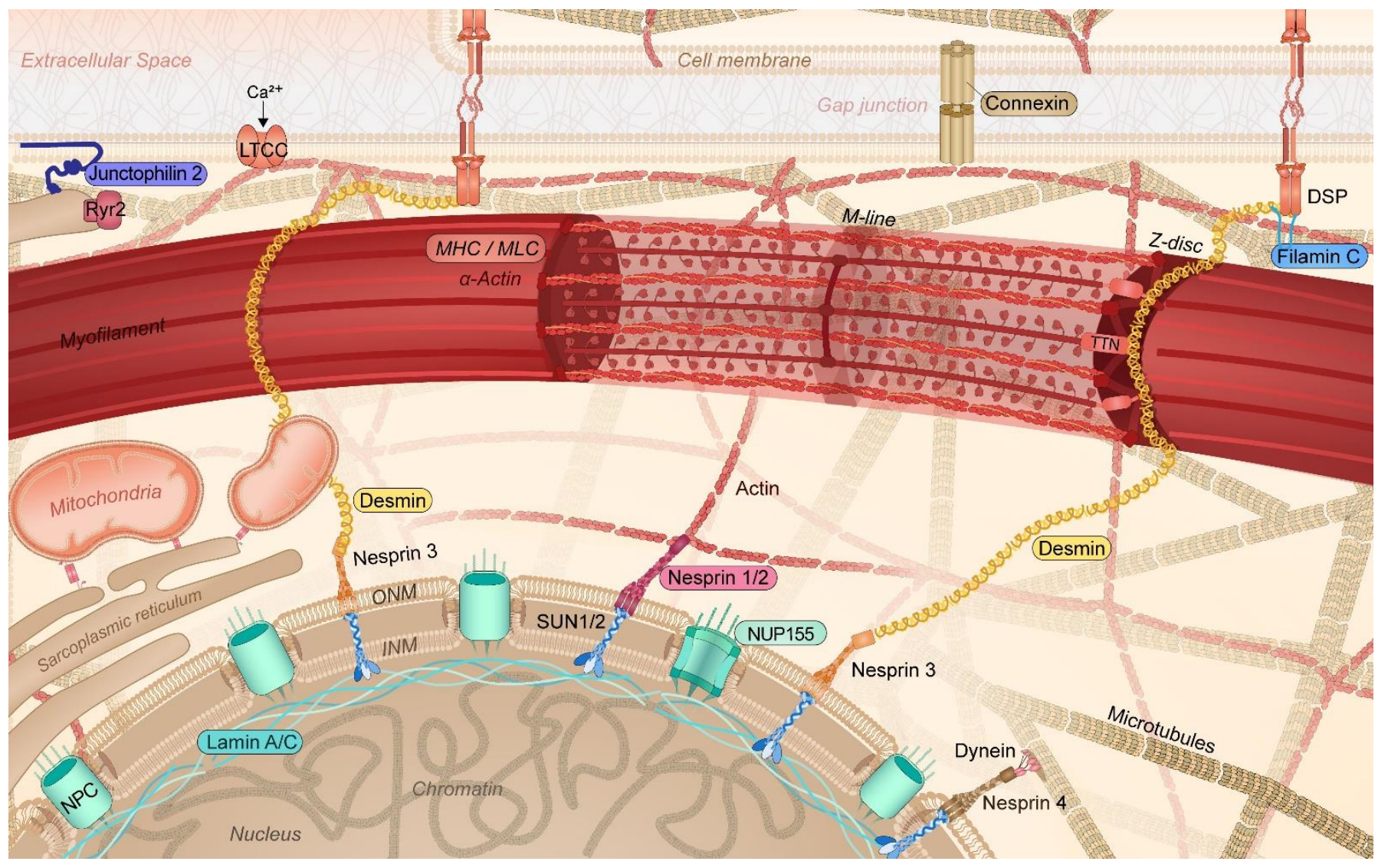

Figure 2. Schematic representation of the specific cytoskeletal protein complexes in cardiomyocytes linked to the onset of AF. Cytoskeletal (-associated) protein variants related to AF are highlighted (colored box). DSP: desmoplakin; INM: inner nuclear membrane; LTCC: L-type calcium channel; MHC: myosin heavy chain; MLC: myosin light chain; NPC: nuclear pore complex; NUP155: nucleoporin 155; Ryr2: ryanodine receptor 2; TTN: titin; ONM: outer nuclear membrane; SUN1/2: Sad1p, UNC-84 domain-containing protein $1 / 2$.

\section{Cytoskeletal (-Associated) Variants Associated with Clinical AF}

In approximately $15 \%$ of $\mathrm{AF}$ patients, $\mathrm{AF}$ occurs in the absence of common risk factors and at a younger age [1]. In these patients, AF may be familial, suggesting a heritable genetic predisposition. To explore the role of gene variations in $\mathrm{AF}$, the emergence of exome and genome sequencing data has provided extensive new data and revealed a previously unsuspected link between AF and several cytoskeletal (-associated) proteins (Table 1).

Recently, several AF families have been identified to carry a mutation in genes encoding the intermediate filament proteins lamin A/C (LMNA), desmin (DES), and titin (TTN) [31-34] (Table 1). Intermediate filament proteins integrate the outer cell membrane via desmoplakin $(D S P)$, with sarcomeric proteins such as titin, Z-disk, and the nuclear membrane, thereby regulating the sarcomere architecture and function as well as the nu- 
clear morphology, DNA stability, and gene expression (Figure 2) [6,35-37]. Variants in these cytoskeletal proteins are known to be associated with the development of dilated cardiomyopathy (DCM), hypertrophic cardiomyopathy (HCM), and peripartum cardiomyopathy (PPCM) [38-41]. Of note, various studies have revealed that early-onset AF often represents the initial manifestation of the cardiac phenotype, sometimes even preceding cardiomyopathy by several years, and in the absence of common risk factors as well as gross structural changes in the heart. This observation indicates that $\mathrm{AF}$ is a direct consequence of the mutation rather than being caused by structural abnormalities in the ventricle $[42,43]$. Over $50 \%$ of $L M N A$ [31,42,44], 60\% of DES [32] and 30-60\% of TTN [34] mutant carriers develop cardiac conduction disorders, arrhythmias, and atrial tachycardia, including AF. Furthermore, these patients reveal a more progressive form of cardiac disease with poor outcomes. These findings are further supported by other studies. In a Chinese family, four subjects revealed an AV block, and three of them suffered from $\mathrm{AF}$, which was related to a new frameshift insertion in the $L M N A$ gene (c.825_826insCAGG) [45]. In addition, in a study in Italian families with $L M N A$ variants [46], a total of 30 subjects were included, of which 19 were positive and 11 were negative for $L M N A$ variants. Of the 19 positive study subjects, 11 showed early AF versus none of the 11 negative subjects. These studies reveal a clear association between $L M N A$ variants and the development of AF.

Interestingly, a recent study including early-onset familial AF patients uncovered the phosphodiesterase-4D-interacting-protein (PDE4DIP) p.A123T mutation as a genetic modifier of DES p.S13F [47]. PDE4DIP p.A123T increases the penetrance of cardiac arrest and early-onset $\mathrm{AF}$ in the DES mutation carriers. These findings suggest an epistatic interaction of DPE4DIP with the DES gene, leading to increased penetrance of both traits and AF promotion [47].

Interestingly, a recent study identified multiple index patients with DCM carried an identical mutation (c.59926 + 1G>A) in the TTN gene, encoding the giant titin protein, which is the major gene underlying inherited DCM. The identified variant likely leads to truncated titan (TTNtv), which is associated with AF onset [34,53]. In an important subset (53\%) of index patients and their family members carrying this founder mutation, atrial tachyarrhythmias, in particular AF, were demonstrated. In three patients, AF preceded the development of TTNtv-associated DCM by 11-14 years [34]. In patients with TTNtvassociated DCM and AF, left atrial enlargement was not noticed in half of them. In addition, the traditional risk factors for AF were absent, suggesting a potential intrinsic effect of TTNtv [34], which is in line with the study of Ahlberg et al. [53]. Together, these data strongly suggest that (paroxysmal) AF is an important part of the clinical disease spectrum caused by TTNtv, even if major structural heart abnormalities are still absent, and the individual does not present traditional risk factors for AF. However, the underlying mechanism of TTNtv causing cardiomyocyte structural and contractile remodeling and, consequently, AF remains to be elucidated.

Thus, emerging evidence has identified novel variants in cytoskeletal proteins to underlie early AF (Table 1). Currently, no detailed mechanistic explanation, treatment modalities, or diagnostic screening tools for genetic AF are available. To overcome this, we first need to understand the mutation-specific molecular pathways that drive genetic AF. This knowledge may ultimately lead to the identification of novel drug targets and therapeutic and diagnostic strategies. 
Table 1. Overview of cytoskeletal (-associated) protein variants, identified with whole genome sequencing, that relate to genetic AF.

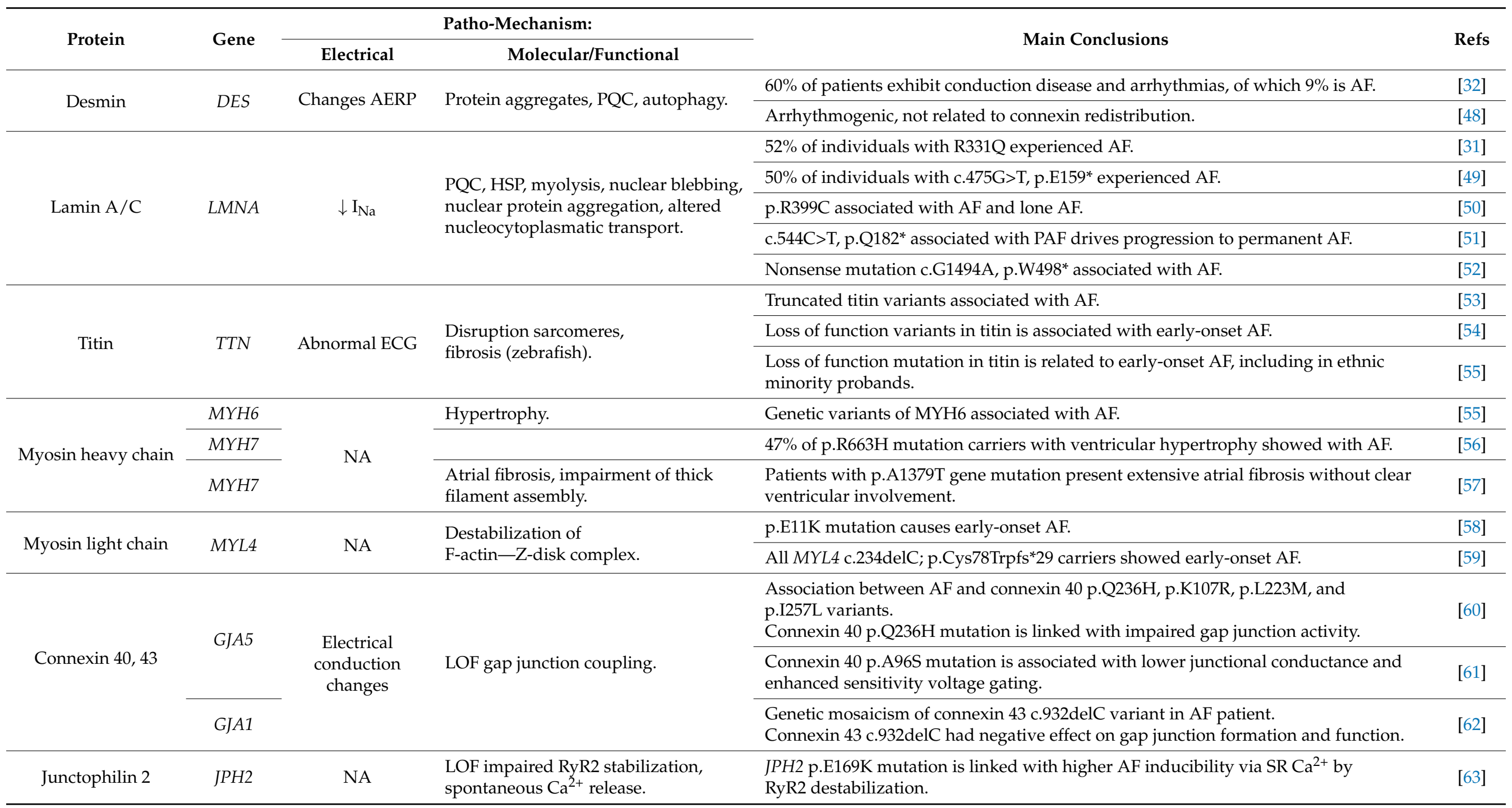


Table 1. Cont.

\begin{tabular}{|c|c|c|c|c|c|}
\hline \multirow{2}{*}{ Protein } & \multirow{2}{*}{ Gene } & \multicolumn{2}{|r|}{ Patho-Mechanism: } & \multirow{2}{*}{ Main Conclusions } & \multirow{2}{*}{ Refs } \\
\hline & & Electrical & Molecular/Functional & & \\
\hline Nucleoporin 155 & NUP155 & $\begin{array}{l}\text { ECG } \\
\text { abnormalities, } \\
\text { APD } \downarrow\end{array}$ & $\begin{array}{l}\text { LOF nuclear localization, loss nuclear } \\
\text { permeability for HSP70. }\end{array}$ & $\begin{array}{l}\text { NUP155 p.R391H human mutation associated with AF. } \\
\text { Mutant NUP155 mice presented reduced atrial AP duration and impaired } \\
\text { nucleocytoplasmic transport of HSP70. }\end{array}$ & [64] \\
\hline Nesprin 2 & SYNE2 & NA & $\begin{array}{l}\text { SYNE is involved in RNA polymerase } \\
\text { II binding and alternative splicing. }\end{array}$ & SYNE2 A + 688G mutation associated with AF. & [65] \\
\hline Filamin C & FLNC & $\begin{array}{c}\text { ECG } \\
\text { abnormalities }\end{array}$ & $\begin{array}{l}\text { Reduced localization at Z-disk, but } \\
\text { preserved at intercalated disk. } \\
\text { Diminished contractile activity. }\end{array}$ & $\begin{array}{l}\text { FLNC variants are linked with AF. } \\
\text { FLNC p.V2297M mutation causes cardiomyocyte dysfunction. }\end{array}$ & {$[66]$} \\
\hline
\end{tabular}

AERP: atrial effective refractory period; AF: atrial fibrillation; PAF: paroxysmal AF; AP: action potential; ECG: electrocardiogram LOF: loss of function; NA: not available. 


\section{Pathophysiological Mechanisms Driving Cytoskeletal Protein Mutation-Induced AF}

As mentioned previously, all cytoskeletal proteins are linked via the microtubule network with the outer cell membrane, the sarcomeric proteins, and the nuclear membrane, and thereby regulate sarcomere architecture and function as well as nuclear morphology, DNA stability, and gene expression (Figure 2) $[19,67,68]$. The malfunction of cytoskeletal proteins has been associated with cardiac manifestations such as compromised conduction disorders and arrhythmogenesis and, as such, contributed to clinical phenotypes compatible with DCM as well as AF [69]. Knowledge of the molecular mechanisms underlying cytoskeletal protein mutation-induced AF is needed to develop therapeutic and diagnostic tools for these patients. Although research findings provide some preliminary insights into underlying mechanisms, as, for example, TTNtv, as described above, most findings are still in their infancy (Figure 3).

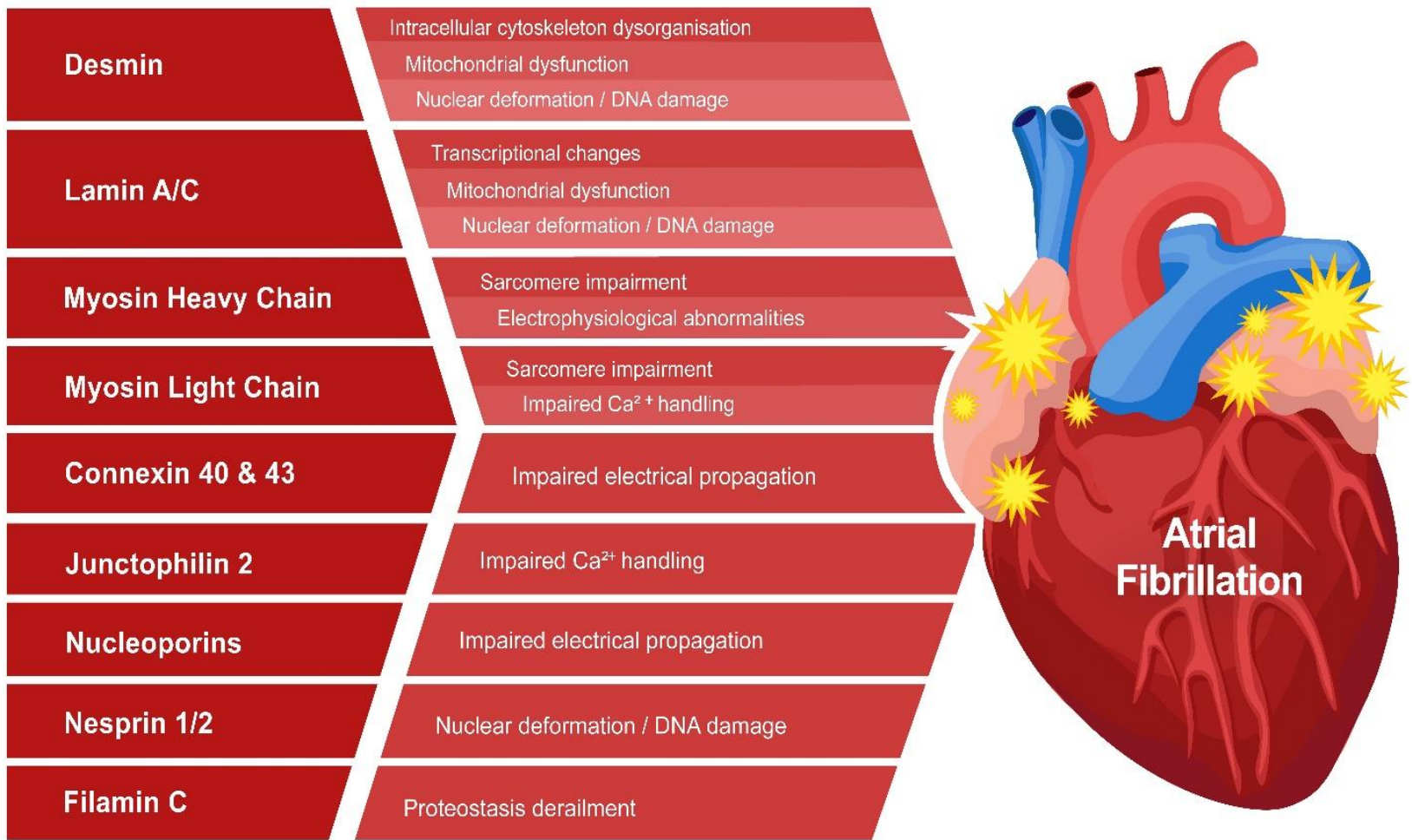

Figure 3. Overview of potential pathophysiological pathways of cytoskeletal (-associated) protein variants driving AF.

\subsection{Desmin Variant-Induced Remodeling}

Desmin is one of the intermediate filaments that integrates the sarcolemma, Z disk, and nuclear membrane in sarcomeres and regulates sarcomere architecture. Desmin is encoded by the DES gene and highly expressed in the heart, the conduction system of the heart, and the pulmonary vein myocardial sleeve, which is the original focus of AF.

A previous study in desmin knockout mice showed a reduction in the atrial refractory period and increased susceptibility for AF [48], suggesting a key role of desmin dysfunction as a molecular substrate for the onset of AF. Isolated sinoatrial nodes from $D E S^{-/-}$ mice showed a significant increase in pacemaker potentials and diastolic depolarizations. Furthermore, these mice showed increased PR intervals and P wave durations combined with supraventricular premature beats, which may trigger AF onset [70].

The role of desmin in AF promotion has been confirmed by various additional studies. In iPSC-derived cardiomyocytes expressing the homozygous mutation DES p.Y122H [71] and the myocardial tissue of patients carrying DES p.A120D [72], impaired assembly of 
the intermediate filament structure and the presence of cytosolic desmin aggregates were observed. Importantly, variants in DES near the c-terminus of the protein tend not to hamper filament formation; however, they interfere with the mechanical properties of the desmin network [73,74].

Moreover, in a mouse model for desmin-related cardiomyopathy, it was shown that mitochondrial dysfunction preceded the onset of cardiac remodeling and pathological heart function [75]. Here, desmin misfolding suppresses mitochondrial respiration and membrane potential and increases the ADP/ATP ratio and mitochondrial DNA (mtDNA) release, which was accompanied by the disruption of the cardiomyocyte cytoskeletal network [76]. Interestingly, cardiac remodeling was shown to be subject to mitochondrial dysfunction in both experimental models for AF and clinical AF [5].

Furthermore, desmin dysfunction is also linked to cardiomyopathy without being directly linked to a specific desmin mutation. In a cardiomyopathy Lmna ${ }^{H 222 P / H 222 P}$ mouse model, desmin organization was disrupted and accumulated in the cytoplasm. Moreover, desmoplakin, plakoglobin, and connexin-43 were mislocalized, and mitochondrial function was impaired. Interestingly, all the effects were ameliorated by the cardiac-specific overexpression of $\alpha \mathrm{B}$-crystallin [77].

The depletion of desmin in ventricular cardiomyocytes derived from a rat leads to nuclear involution, the infolding of the nuclear lamina, and DNA damage driven by the microtubule network, as well as loss in contractile function [78]. A similar phenotype is seen when depleting the desmin binding partner nesprin 3, which links desmin to the nucleus [78]. This points to desmin as an important protein in the linker of nucleoskeleton and cytoskeleton (LINC) complex and for the maintenance of a proper nuclear shape in cardiomyocytes. This notion was further supported by the rescue of nuclear shape in desmin knockout rats by disrupting the connection between nesprins and Sad1p/UNC84 (SUN) domain-containing proteins via dominant-negative KASH (Klarsicht, ANC1, syne homology) peptides (DN-KASH) [78].

Thus, the findings indicate a key role of desmin dysfunction in AF onset. Desmin dysfunction may result in desmin aggregate formation, mitochondrial dysfunction, and disruption of the cytoskeletal network.

\subsection{Mutations in Lamin A/C}

The lamin $\mathrm{A} / \mathrm{C}$ are type $\mathrm{V}$ intermediate filament proteins expressed in terminally differentiated somatic cells, encoded by the LMNA gene [79,80]. As lamin A/C are expressed in the nuclear envelope, they provide structural function and transcriptional regulation in the cell nucleus. How $L M N A$ variants cause AF onset is unknown, but experimental data from cardiomyopathy and myopathy studies may identify potential mechanisms.

A recent study utilizing induced pluripotent stem cell-derived cardiomyocytes (iPSC-CM) from DCM patients with an $L M N A$ p.E342K variant showed a decrease in the spontaneous contraction rate and $\mathrm{I}_{\mathrm{f}}$ density, a prolonged APD and increased $\mathrm{I}_{\mathrm{Ca}, \mathrm{L}}$, and an increase in arrhythmias [81]. Ventricular cardiomyocytes isolated from $L M N A^{\mathrm{N} 195 \mathrm{~K} / \mathrm{N} 195 \mathrm{~K}}$ mice also showed a prolonged APD and exhibited a significant increase in both the peak and late $\mathrm{I}_{\mathrm{Na}}$ [82]. These experimental findings indicate that $L M N A$ variants result in electrophysiological alterations, which may drive AF.

The nuclear lamin A/C regulates transcription factors either by sequestering them to the nuclear periphery or by a mechanism involved in activating specific signaling pathways [83,84]. Furthermore, lamin A/C interacts with chromatin by binding to specific genomic regions defined as lamin-associated domains (LADs) [85]. In a recent study on patient iPSC-derived LMNA p.K219T cardiomyocytes, mutant lamin A/C suppressed sodium channel SCN5A expression, resulting in diminished $\mathrm{I}_{\mathrm{Na}}$ and impaired signal propagation [86].

So far, studies in ventricular cardiomyocytes revealed $L M N A$ variants to result in cytoskeletal and microtubule disruption [35,37,77], dysmorphology of the nuclei [37], activation of the DNA damage response [87], and PARP1 activation [39,88]. PARP1 activation results in the consumption of mitochondrial $\mathrm{NAD}^{+}$levels [88], which drive cardiomyocyte 
dysfunction and cardiomyopathy onset [39,89]. In DCM, all these effects were ameliorated by supplementation with a precursor of $\mathrm{NAD}^{+}$, nicotinamide [39], or conservation of the cytoskeletal network with geranylgeranylacetone (GGA), a heat shock protein (HSP)inducer [77]. Importantly, the activation of the DNA damage-PARP1-NAD ${ }^{+}$depetion axis has also been found to drive 'wear and tear' AF [90,91], indicating a potential key pathway in LMNA mutation-induced AF.

Furthermore, minor deviations on lamin A/C are linked to morphological abnormities of the nucleus that cause increased nuclear fragility and mechanosensitivity [92]. Emerging research findings uncovered that the expressions of the various lamin subtypes are dependent on the degree of mechanical stress. A-type lamins are viscoelastic and, therefore, provide structural stiffness, whereas the elastic B-type lamins allow nuclear deformability $[93,94]$. Mechanotransduction between the structural components of the cardiomyocyte requires the interaction of lamin $\mathrm{A} / \mathrm{C}$ with the proteins involved in the LINC complex [95]. Interestingly, the disruption of the LINC complex significantly ameliorates DCM progression, prolongs longevity, and helps to retain nuclear morphology. The findings indicate that the LINC complex plays a detrimental role in nuclear morphology and cardiac disease progression in $L M N A$-compromised mice [96]. Whether $L M N A$ variants drive AF due to mechanostress transduction on the nucleus via the LINC complex, to changes in transcription and chromosomal organization, or due to an interplay between both remains to be elucidated.

\subsection{Variants in Myosin Heavy Chain}

The two isoforms of cardiac myosin heavy chain (MYH), $\alpha$ and $\beta$, are coded by the MYH6 and MYH7 genes, respectively. The atrial myocardium expresses $\alpha \mathrm{MYH}$, and the ventricular myocardium expresses $\beta \mathrm{MYH}$. $M Y H 7$ gene variants are associated with a variety of cardiomyopathies in humans, including HCM [97] and DCM [98]. Emerging evidence also indicates that $\mathrm{MYH} 6$ variants may result in AF. A large whole-genome sequencing study in Icelanders showed that a missense variant in MYH6 p.R721W is related to several cardiac diseases, particularly conduction disorders, including AF and sick sinus syndrome [99].

Furthermore, miR-208a is encoded by the intron of $M Y H 6$, which is a cardiac-specific highly conserved microRNA (miRNA). In mice, miR-208a regulates normal cardiac conduction and is required for the expression of GJA5 (Cx40), indicating a link between MYH6 and GJA5 expression and cardiomyocyte function via miR-208a [100]. Recent experimental findings in MYH6 knockout zebrafish show the activation of the ER stress pathway and enlargement of the cardiomyocytes [101]. In HL-1 and isolated rat atrial cardiomyocytes, the overexpression of $\mathrm{MYH} 6$ resulted in sarcomere impairment, electrophysiological abnormalities, and a slower conduction velocity [102]. As AF is also associated with all these endpoints, comparable pathways may play a role in mutant $M Y H 6$-induced AF.

\subsection{Mutation in Myosin Light Chain}

Myosin light-chain 4 (MYL4) is important for the contractile function of the cardiomyocytes. Variants in the MYL4 gene have been associated with clinical AF and have been further explored in experimental studies [58]. In zebrafish, mutant MYL4 leads to the disruption of the sarcomeric structure, atrial enlargement, and electrical abnormalities. These changes are also observed in clinical AF. In addition, electron microscopic studies revealed myofibrillar disarray and the disappearance of Z-disks, which were related to the destabilization of the F-actin-Z-disk complex, impaired $\mathrm{Ca}^{2+}$ signaling, and the onset of atrial myopathy and atrial arrhythmia [58]. Comparable molecular and structural adaptations in the cardiomyocytes may also drive MYL4 mutation-induced AF.

\subsection{Mutations in Connexin-40 and Connexin-43}

Connexins are channel proteins that form hemichannels specialized in cell-to-cell communication at the intercalated disks [103]. Connexins enable the passive diffusion of 
compounds up to $1 \mathrm{kDa}$ between two connected cells [104]. Depending on the connexin isoform, they transport water, ions, and second messengers, such as IP3, ADP, ATP, cAMP, and miRNAs [104]. Because of this role, connexins play a vital role in the heart by coordinating the depolarization of cardiac muscle and ensuring cardiac muscle function. The primary atrial connexin proteins are connexin-43 (Cx43) and connexin-40 (Cx40), encoded by GJA1 and GJA5, respectively [105]. Abnormalities in connexin levels, function, or localization impair electrical propagation and can lead to the initiation and/or stabilization of reentry circuits that support AF [105]. Moreover, Cx40 and Cx43 get mislocalized in case of $L M N A$ variant-induced cytoskeletal changes [36,77,106,107] and DES variants [108]. This observation indicates that impairment in the cytoskeletal network at a specific location affects the network as a whole.

In 'wear and tear' AF, reduced Cx40 but not Cx43 levels were found in the atrial tissue of patients with AF compared to controls [109]. As such, several Cx40 mutants have been associated with clinical AF onset [110]. HL-1 atrial cardiomyocytes overexpressing functional Cx40 mutants G38D, V85I, or L229M, resulted in protein instability and accelerated degradation by the proteasome. Similarly, Cx40 mutants cause the gain of the function of hemichannels (half of the gap junction channels) [111,112], resulting in altered conductive and permeability properties [113], which may drive Cx40 mutant-induced AF.

\subsection{Variants in Junctophilin 2}

Junctophilin 2 (JPH2) is a member of the junctophilin gene family, which plays an important role in $\mathrm{SR} \mathrm{Ca}^{2+}$ handling and the modulation of ryanodine receptors (RyRs) [114]. Beavers et al. screened 203 unrelated HCM patients and uncovered the JPH2 p.E169K variant in two patients with juvenile-onset paroxysmal AF [63]. Follow-up studies in mouse models demonstrated that mice expressing JPH2 p.E169K exhibited a higher incidence of inducible AF compared to wild-type mice [63]. These changes were attributed to reduced binding of JPH2 p.E169K to RyR2, resulting in abnormal $\mathrm{Ca}^{2+}$ release events, which are associated with AF [63]. In addition, atrial JPH2 protein levels in mice correlated negatively with the incidence of pacing-induced AF, indicating a crucial role of JPH2 in atrial cardiomyocyte function and AF promotion [115].

\subsection{Variants in Nucleoporins}

Nucleoporins (NUPs) are the critical molecular components for the assembly and function of the nuclear pore complex (NPC). The NPC is composed of 30 different nucleoporins that are each present in multiple copies [116] and contain cytoplasmic and nucleoplasmic filaments [117]. The filaments consist of microfilaments, intermediate filaments, and myosin filaments, which are all part of the cytoskeletal network. In addition, NPCs interact with the LINC-complex [118]. Due to its localization in the cardiomyocytes, NUPs are cytoskeletal-associated proteins [119].

Alterations in the NPC have been related to a variety of cardiac diseases, such as heart failure [120,121] and AF [64]. The first observation describing the relation between NUP and AF was a study including a large consanguineous AF family from Uruguay and South America, with 57 family members carrying the NUP155 p.R391H variation [122] Follow-up studies in mouse models demonstrated that the homozygous $\mathrm{R} 391 \mathrm{H}$ variation in NUP155 resulted in impaired nuclear localization of NUP155, reduced nuclear envelope permeability for HSP70, shortened action potential duration, and AF onset [64]. In addition, NUP155 is an essential gene, as NUP $155^{-/-}$knockout mice died during embryogenesis,

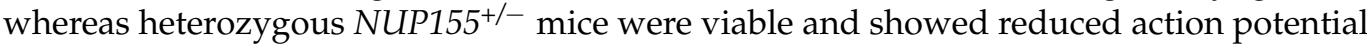
durations, which may relate to AF onset [64]. Similarly, a study expressing truncated NUP155 in mouse embryonic stem cell lines showed impaired genome integrity compared to controls, which may also underlie AF [123]. 


\subsection{Variants in Nesprin-1/2}

Nesprins (SYNE) are a family of multi-isomeric scaffolding proteins. Nesprin $1 / 2$ are located at the nuclear envelope and interact with SUN domain-containing proteins, lamin A/C and emerin, to form the LINC complex (Figure 2) [124]. The LINC complex provides a stable physical connection between the nucleus and the cytoskeleton [124]. As mentioned above, the LINC complex participates in many cellular activities, including the maintenance of nuclear morphology, nuclear positioning, the mediation of mechanical cell signaling, and downstream gene regulation. Nesprin $1 / 2$ are highly expressed in skeletal and cardiac muscles. Recent studies showed that variants in SYNE1 are linked to nuclear morphological changes and the mislocalization of and perturbed interaction with binding partners lamin A/C, emerin, and SUN2 [124,125]. Furthermore, variants in the SYNE1 and SYNE2 isoforms are also linked to abnormal mechanotransduction and altered gene expression [126]. These findings indicate that variants in nesprin may result in the derailment of the cytoskeletal network comparable to other mutant LINC-associated proteins, including lamin A/C and, as such, may drive AF.

\subsection{Variants in Filamin $C$}

Filamin C (FLNC) is one of three filamin protein that participates in sarcomere stability [127]. Filamin $C$ is most commonly found in skeletal and cardiac muscles and is localized to the Z-disc, myotendinous junctions, the sarcolemma, and intercalated discs. FLNC variants may lead to proteostasis derailment, such as protein misfolding and aggregation and, consequently, the saturation of the ubiquitin-proteasome and autophagy pathways [128]. Since 'wear and tear' AF is also associated with proteostasis derailment and autophagic protein degradation, a comparable pathway may drive mutant FLNC-induced AF.

\section{Conclusions}

In $15 \%$ of $\mathrm{AF}$ patients, $\mathrm{AF}$ is caused by gene variants. Although emerging research findings indicate that variants in cytoskeletal (-associated) proteins may trigger early AF onset, knowledge on the underlying pathophysiological mechanisms is still in its infancy. Recent findings suggest that cytoskeletal (-associated) protein variants cause disruption of the structural network, mitochondrial dysfunction, electrophysiological changes, DNA damage-induced PARP1 activation, and $\mathrm{NAD}^{+}$depletion. As several of these mechanisms are also found to play a key role in 'wear and tear' $\mathrm{AF}$, they may represent canonical pathophysiological pathways driving AF. Future research on cytoskeletal (-associated) protein variants should be directed at the dissection of the molecular root causes driving $\mathrm{AF}$ and the identification of novel druggable targets for therapy. As no treatments are available for variant carriers, these studies are clinically highly relevant.

Author Contributions: Conceptualization, S.W.v.W., W.S. and B.J.J.M.B.; writing-original draft preparation, S.W.v.W., W.S., L.F.J.M.W., K.S.R. and B.J.J.M.B.; writing—review and editing, S.W.v.W., W.S., K.S.R. and B.J.J.M.B.; visualization, L.F.J.M.W., S.W.v.W. and B.J.J.M.B.; supervision, B.J.J.M.B.; funding acquisition, B.J.J.M.B. All authors have read and agreed to the published version of the manuscript.

Funding: This research was funded by DHF, DZKH (DnAFix project, 2020B003, 2020) and the Atrial Fibrillation Innovation Platform (www.AFIPonline.org, accessed on 9 December 2021).

Conflicts of Interest: The authors declare no conflict of interest.

\section{References}

1. Hindricks, G.; Potpara, T.; Dagres, N.; Arbelo, E.; Bax, J.J.; Blomström-Lundqvist, C.; Boriani, G.; Castella, M.; Dan, G.-A.; Dilaveris, P.E.; et al. 2020 ESC Guidelines for the diagnosis and management of atrial fibrillation developed in collaboration with the European Association for Cardio-Thoracic Surgery (EACTS): The Task Force for the diagnosis and management of atrial fibrillation of the European Society of Cardiology (ESC) Developed with the special contribution of the European Heart Rhythm Association (EHRA) of the ESC. Eur. Heart J. 2021, 42, 373-498. [CrossRef] [PubMed] 
2. De Groot, N.M.; Houden, R.P.; Smeets, J.L.; Boersma, E.; Schotten, U.; Schalij, M.J.; Crijns, H.; Allessie, M.A. Electropathological substrate of longstanding persistent atrial fibrillation in patients with structural heart disease: Epicardial breakthrough. Circulation 2010, 122, 1674-1682. [CrossRef] [PubMed]

3. Zhang, D.; Wu, C.T.; Qi, X.Y.; Meijering, R.A.M.; Hoogstra-Berends, F.; Tadevosyan, A.; Deniz, G.C.; Durdu, S.; Akar, A.R.; Sibon, O.C.M. Activation of Histone Deacetylase-6 (HDAC6) Induces Contractile Dysfunction through Derailment of $\alpha$-Tubulin Proteostasis in Experimental and Human Atrial Fibrillation. Circulation 2014, 129, 346-358. [CrossRef] [PubMed]

4. Brundel, B.J.; Ausma, J.; Van Gelder, I.C.; van der Want, J.; van Gilst, W.; Crijns, H.J.; Henning, R. Activation of proteolysis by calpains and structural changes in human paroxysmal and persistent atrial fibrillation. Cardiovasc. Res. 2002, 54, 380-389. [CrossRef]

5. Wiersma, M.; Van Marion, D.M.; Wüst, R.C.; Houtkooper, R.H.; Zhang, D.; De Groot, N.M.; Henning, R.H.; Brundel, B.J. Mitochondrial Dysfunction Underlies Cardiomyocyte Remodeling in Experimental and Clinical Atrial Fibrillation. Cells 2019, 8, 1202. [CrossRef] [PubMed]

6. Henning, R.H.; Brundel, B. Proteostasis in cardiac health and disease. Nat. Rev. Cardiol. 2017, 14, 637-653. [CrossRef] [PubMed]

7. Msc, R.S.; Knops, P.; Ramos, K.S.; Roos-Serote, M.C.; Bogers, A.J.; Brundel, B.J.; Groot, N.M. Atrial fibrillation fingerprinting; spotting bio-electrical markers to early recognize atrial fibrillation by the use of a bottom-up approach (AFFIP): Rationale and design. Clin. Cardiol. 2020, 43, 546-552. [CrossRef]

8. Waldmann, V.; Laredo, M.; Abadir, S.; Mondésert, B.; Khairy, P. Atrial fibrillation in adults with congenital heart disease. Int. J. Cardiol. 2019, 287, 148-154. [CrossRef]

9. Teuwen, C.P.; De Groot, N.M. Atrial Fibrillation: The Next Epidemic for Patients With Congenital Heart Disease. J. Am. Coll. Cardiol. 2017, 70, 2949-2950. [CrossRef]

10. Teuwen, C.P.; Korevaar, T.I.; Coolen, R.L.; Van Der Wel, T.; Houck, C.A.; Evertz, R.; Yaksh, A.; Roos-Hesselink, J.W.; Bogers, A.J.; De Groot, N.M. Frequent atrial extrasystolic beats predict atrial fibrillation in patients with congenital heart defects. Europace 2016, 20, 25-32. [CrossRef]

11. Darbar, D.; Herron, K.J.; Ballew, J.D.; Jahangir, A.; Gersh, B.J.; Shen, W.-K.; Hammill, S.C.; Packer, D.L.; Olson, T.M. Familial atrial fibrillation is a genetically heterogeneous disorder. J. Am. Coll. Cardiol. 2003, 41, 2185-2192. [CrossRef]

12. Lubitz, S.A.; Yin, X.; Fontes, J.D.; Magnani, J.W.; Rienstra, M.; Pai, M.; Villalon, M.L.; Vasan, R.S.; Pencina, M.J.; Levy, D.; et al. Association Between Familial Atrial Fibrillation and Risk of New-Onset Atrial Fibrillation. JAMA 2010, 304, 2263-2269. [CrossRef] [PubMed]

13. Palatinus, J.A.; Das, S. Your Father and Grandfather's Atrial Fibrillation: A Review of the Genetics of the Most Common Pathologic Cardiac Dysrhythmia. Curr. Genom. 2015, 16, 75-81. [CrossRef] [PubMed]

14. Tucker, N.R.; Clauss, S.; Ellinor, P.T. Common variation in atrial fibrillation: Navigating the path from genetic association to mechanism. Cardiovasc. Res. 2016, 109, 493-501. [CrossRef] [PubMed]

15. Zhang, J.; Johnsen, S.P.; Guo, Y.; Lip, G.Y. Epidemiology of Atrial Fibrillation: Geographic/Ecological Risk Factors, Age, Sex, Genetic. Card. Electrophysiol. Clin. 2021, 13, 1-23. [CrossRef]

16. Coppini, R.; Santini, L.; Olivotto, I.; Ackerman, M.J.; Cerbai, E. Abnormalities in sodium current and calcium homoeostasis as drivers of arrhythmogenesis in hypertrophic cardiomyopathy. Cardiovasc. Res. 2020, 116, 1585-1599. [CrossRef]

17. Wiersma, M.; Henning, R.; Brundel, B.J. Derailed Proteostasis as a Determinant of Cardiac Aging. Can. J. Cardiol. 2016, 32, 1166.e11-1166.e20. [CrossRef]

18. Meijering, R.A.; Henning, R.H.; Brundel, B.J. Reviving the protein quality control system: Therapeutic target for cardiac disease in the elderly. Trends Cardiovasc. Med. 2015, 25, 243-247. [CrossRef]

19. Knöll, R.; Buyandelger, B.; Lab, M. The Sarcomeric Z-Disc and Z-Discopathies. J. Biomed. Biotechnol. 2011, 2011, 1-12. [CrossRef]

20. Phillips, M.J.; Voeltz, G.K. Structure and function of ER membrane contact sites with other organelles. Nat. Rev. Mol. Cell Biol. 2015, 17, 69-82. [CrossRef]

21. Lewis, S.C.; Uchiyama, L.F.; Nunnari, J. ER-mitochondria contacts couple mtDNA synthesis with mitochondrial division in human cells. Science 2016, 353, aaf5549. [CrossRef] [PubMed]

22. Pool, L.; Wijdeveld, L.; de Groot, N.; Brundel, B. The Role of Mitochondrial Dysfunction in Atrial Fibrillation: Translation to Druggable Target and Biomarker Discovery. Int. J. Mol. Sci. 2021, 22, 8463. [CrossRef] [PubMed]

23. Wiersma, M.; Meijering, R.A.M.; Qi, X.; Zhang, D.; Liu, T.; Hoogstra-Berends, F.; Sibon, O.C.M.; Henning, R.H.; Nattel, S.; Brundel, B.J.J.M. Endoplasmic Reticulum Stress Is Associated With Autophagy and Cardiomyocyte Remodeling in Experimental and Human Atrial Fibrillation. J. Am. Hear. Assoc. 2017, 6, e006458. [CrossRef] [PubMed]

24. Ausma, J.; Dispersyn, G.D.; Duimel, H.; Thoné, F.; Donck, L.V.; A Allessie, M.; Borgers, M. Changes in Ultrastructural Calcium Distribution in Goat Atria During Atrial Fibrillation. J. Mol. Cell. Cardiol. 2000, 32, 355-364. [CrossRef] [PubMed]

25. Friedman, J.R.; Lackner, L.L.; West, M.; DiBenedetto, J.R.; Nunnari, J.; Voeltz, G.K. ER Tubules Mark Sites of Mitochondrial Division. Science 2011, 334, 358-362. [CrossRef] [PubMed]

26. Hu, X.; Li, J.; van Marion, D.M.; Zhang, D.; Brundel, B.J. Heat shock protein inducer GGA*-59 reverses contractile and structural remodeling via restoration of the microtubule network in experimental Atrial Fibrillation. J. Mol. Cell. Cardiol. 2019, 134, 86-97. [CrossRef]

27. Li, J.; Zhang, D.; Brundel, B.J.J.M.; Wiersma, M. Imbalance of ER and Mitochondria Interactions: Prelude to Cardiac Ageing and Disease? Cells 2019, 8, 1617. [CrossRef] 
28. Lemon, D.D.; Horn, T.R.; Cavasin, M.A.; Jeong, M.Y.; Haubold, K.W.; Long, C.; Irwin, D.C.; McCune, S.A.; Chung, E.; Leinwand, L.; et al. Cardiac HDAC6 catalytic activity is induced in response to chronic hypertension. J. Mol. Cell. Cardiol. 2011, 51, 41-50. [CrossRef]

29. Friedman, J.R.; Webster, B.M.; Mastronarde, D.N.; Verhey, K.J.; Voeltz, G.K. ER sliding dynamics and ER-mitochondrial contacts occur on acetylated microtubules. J. Cell Biol. 2010, 190, 363-375. [CrossRef]

30. Lehmann, L.; Worst, B.C.; Stanmore, D.A.; Backs, J. Histone deacetylase signaling in cardioprotection. Cell. Mol. Life Sci. 2013, 71, 1673-1690. [CrossRef]

31. Hoorntje, E.T.; Bollen, I.A.; Barge-Schaapveld, D.Q.; Van Tienen, F.H.; Meerman, G.J.T.; Jansweijer, J.A.; Van Essen, A.J.; Volders, P.G.; Constantinescu, A.A.; Akker, P.C.V.D.; et al. Lamin A/C-Related Cardiac Disease: Late Onset With a Variable and Mild Phenotype in a Large Cohort of Patients With the Lamin A/C p.(Arg331Gln) Founder Mutation. Circ. Cardiovasc. Genet. 2017, 10, e001631. [CrossRef] [PubMed]

32. Van Spaendonck-Zwarts, K.Y.; van Hessem, L.; Jongbloed, J.D.; de Walle, H.; Capetanaki, Y.; van der Kooi, A.; van Langen, I.; Berg, M.V.D.; van Tintelen, J. Desmin-related myopathy. Clin. Genet. 2010, 80, 354-366. [CrossRef] [PubMed]

33. Karmouch, J.; Zhou, Q.Q.; Miyake, C.Y.; Lombardi, R.; Kretzschmar, K.; Bannier-Hélaouët, M.; Clevers, H.; Wehrens, X.; Willerson, J.T.; Marian, A.J. Distinct Cellular Basis for Early Cardiac Arrhythmias, the Cardinal Manifestation of Arrhythmogenic Cardiomyopathy, and the Skin Phenotype of Cardiocutaneous Syndromes. Circ. Res. 2017, 121, 1346-1359. [CrossRef] [PubMed]

34. Hoorntje, E.T.; Van Spaendonck-Zwarts, K.Y.; Rijdt, W.P.T.; Boven, L.; Vink, A.; Van Der Smagt, J.J.; Asselbergs, F.; Van Wijngaarden, J.; Hennekam, E.A.; Pinto, Y.M.; et al. The first titin (c.59926 + 1G > A) founder mutation associated with dilated cardiomyopathy. Eur. J. Hear. Fail. 2017, 20, 803-806. [CrossRef]

35. Ho, C.Y.; Jaalouk, D.E.; Vartiainen, M.K.; Lammerding, J. Lamin A/C and emerin regulate MKL1-SRF activity by modulating actin dynamics. Nature 2013, 497, 507-511. [CrossRef]

36. Macquart, C.; Jüttner, R.; Rodriguez, B.M.; Le Dour, C.; Lefebvre, F.; Chatzifrangkeskou, M.; Schmitt, A.; Gotthardt, M.; Bonne, G.; Muchir, A. Microtubule cytoskeleton regulates Connexin 43 localization and cardiac conduction in cardiomyopathy caused by mutation in A-type lamins gene. Hum. Mol. Genet. 2018, 28, 4043-4052. [CrossRef]

37. Barateau, A.; Vadrot, N.; Vicart, P.; Ferreiro, A.; Mayer, M.; Héron, D.; Vigouroux, C.; Buendia, B. A Novel Lamin A Mutant Responsible for Congenital Muscular Dystrophy Causes Distinct Abnormalities of the Cell Nucleus. PLoS ONE 2017, 12, e0169189. [CrossRef]

38. Tsikitis, M.; Galata, Z.; Mavroidis, M.; Psarras, S.; Capetanaki, Y. Intermediate filaments in cardiomyopathy. Biophys. Rev. 2018, 10, 1007-1031. [CrossRef]

39. Vignier, N.; Chatzifrangkeskou, M.; Rodriguez, B.M.; Mericskay, M.; Mougenot, N.; Wahbi, K.; Bonne, G.; Muchir, A. Rescue of biosynthesis of nicotinamide adenine dinucleotide protects the heart in cardiomyopathy caused by lamin A/C gene mutation. Hum. Mol. Genet. 2018, 27, 3870-3880. [CrossRef]

40. Stergiopoulos, K.; Lima, F.V.; Yang, J.; Biteker, M.; Ware, J.S.; Seidman, J.G.; Arany, Z. Shared Genetic Predisposition in Peripartum and Dilated Cardiomyopathies. N. Engl. J. Med. 2016, 374, 2601-2602. [CrossRef]

41. Pfeffer, T.J.; Schlothauer, S.; Pietzsch, S.; Schaufelberger, M.; Auber, B.; Ricke-Hoch, M.; List, M.; Berliner, D.; Moulig, V.A.; König, T.; et al. Increased Cancer Prevalence in Peripartum Cardiomyopathy. JACC CardioOncol. 2019, 1, 196-205. [CrossRef] [PubMed]

42. Van Tintelen, J.P.; Hofstra, R.M.W.; Katerberg, H.; Rossenbacker, T.; Wiesfeld, A.C.P.; du Marchie Sarvaas, G.J.; Wilde, A.A.M.; van Langen, I.M.; Nannenberg, E.A.; van der Kooi, A.J.; et al. High yield of LMNA mutations in patients with dilated cardiomyopathy and/or conduction disease referred to cardiogenetics outpatient clinics. Am. Heart J. 2007, 154, 1130-1139. [CrossRef] [PubMed]

43. Kumar, S.; Baldinger, S.H.; Gandjbakhch, E.; Maury, P.; Sellal, J.-M.; Androulakis, A.F.; Waintraub, X.; Charron, P.; Rollin, A.; Richard, P.; et al. Long-Term Arrhythmic and Nonarrhythmic Outcomes of Lamin A/C Mutation Carriers. J. Am. Coll. Cardiol. 2016, 68, 2299-2307. [CrossRef] [PubMed]

44. Hasselberg, N.E.; Haland, T.F.; Saberniak, J.; Brekke, P.; Berge, K.E.; Leren, T.P.; Edvardsen, T.; Haugaa, K. Lamin A/C cardiomyopathy: Young onset, high penetrance, and frequent need for heart transplantation. Eur. Hear. J. 2017, 39, 853-860. [CrossRef] [PubMed]

45. Jia, Z.; Zhang, Y.; Deng, J.; Guo, Y.; Du, Y.; Wang, G.; Xu, J.; Li, X. A novel LMNA indel mutation identified in a family with atrioventricular block and atrial fibrillation. Medicine 2021, 100, e25910. [CrossRef] [PubMed]

46. Gerbino, A.; Forleo, C.; Milano, S.; Piccapane, F.; Procino, G.; Pepe, M.; Piccolo, M.; Guida, P.; Resta, N.; Favale, S.; et al. Pro-inflammatory cytokines as emerging molecular determinants in cardiolaminopathies. J. Cell. Mol. Med. 2021. [CrossRef] [PubMed]

47. Ziki, M.D.A.; Bhat, N.; Neogi, A.; Driscoll, T.P.; Ugwu, N.; Liu, Y.; Smith, E.; Abboud, J.M.; Chouairi, S.; Schwartz, M.A.; et al. Epistatic interaction of PDE4DIP and DES mutations in familial atrial fibrillation with slow conduction. Hum. Mutat. 2021, 42, 1279-1293. [CrossRef]

48. Schrickel, J.W.; Stöckigt, F.; Krzyzak, W.; Paulin, D.; Li, Z.; Lübkemeier, I.; Fleischmann, B.; Sasse, P.; Linhart, M.; Lewalter, T.; et al. Cardiac conduction disturbances and differential effects on atrial and ventricular electrophysiological properties in desmin deficient mice. J. Interv. Card. Electrophysiol. 2010, 28, 71-80. [CrossRef]

49. Yokokawa, T.; Ichimura, S.; Hijioka, N.; Kaneshiro, T.; Yoshihisa, A.; Kunii, H.; Nakazato, K.; Ishida, T.; Suzuki, O.; Ohno, S.; et al. Case reports of a c.475G $>$ T, p.E159* lamin A/C mutation with a family history of conduction disorder, dilated cardiomyopathy and sudden cardiac death. BMC Cardiovasc. Disord. 2019, 19, 298. [CrossRef] 
50. Han, M.; Zhao, M.; Cheng, C.; Huang, Y.; Han, S.; Li, W.; Tu, X.; Luo, X.; Yu, X.; Liu, Y.; et al. Lamin A mutation impairs interaction with nucleoporin NUP155 and disrupts nucleocytoplasmic transport in atrial fibrillation. Hum. Mutat. 2018, 40, 310-325. [CrossRef]

51. Glöcklhofer, C.R.; Steinfurt, J.; Franke, G.; Hoppmann, A.; Glantschnig, T.; Perez-Feliz, S.; Alter, S.; Fischer, J.; Brunner, M.; Rainer, P.P.; et al. A novel LMNA nonsense mutation causes two distinct phenotypes of cardiomyopathy with high risk of sudden cardiac death in a large five-generation family. Europace 2018, 20, 2003-2013. [CrossRef] [PubMed]

52. Zhao, J.; Yao, H.; Li, Z.; Wang, L.; Liu, G.; Wang, D.W.; Liang, Z. A novel nonsense mutation in LMNA gene identified by Exome Sequencing in an atrial fibrillation family. Eur. J. Med. Genet. 2016, 59, 396-400. [CrossRef] [PubMed]

53. Ahlberg, G.; Refsgaard, L.; Lundegaard, P.R.; Andreasen, L.; Ranthe, M.F.; Linscheid, N.; Nielsen, J.B.; Melbye, M.; Haunsø, S.; Sajadieh, A.; et al. Rare truncating variants in the sarcomeric protein titin associate with familial and early-onset atrial fibrillation. Nat. Commun. 2018, 9, 4316. [CrossRef] [PubMed]

54. Choi, S.H.; Weng, L.-C.; Roselli, C.; Lin, H.; Haggerty, C.; Shoemaker, M.B.; Barnard, J.; Arking, D.E.; Chasman, D.I.; Albert, C.; et al. Association Between Titin Loss-of-Function Variants and Early-Onset Atrial Fibrillation. JAMA 2018, 320, $2354-2364$. [CrossRef] [PubMed]

55. Chalazan, B.; Mol, D.; Darbar, F.A.; Ornelas-Loredo, A.; Al-Azzam, B.; Chen, Y.; Tofovic, D.; Sridhar, A.; Alzahrani, Z.; Ellinor, P.; et al. Association of Rare Genetic Variants and Early-Onset Atrial Fibrillation in Ethnic Minority Individuals. JAMA Cardiol. $2021,6,811$. [CrossRef] [PubMed]

56. Gruver, E.; Fatkin, D.; Dodds, G.; Kisslo, J.; Maron, B.J.; Seidman, J.; E Seidman, C. Familial hypertrophic cardiomyopathy and atrial fibrillation caused by Arg663His beta-cardiac myosin heavy chain mutation. Am. J. Cardiol. 1999, 83, 13-18. [CrossRef]

57. Zhang, S.; Wilson, J.; Madani, M.; Feld, G.; Greenberg, B. Atrial Arrhythmias and Extensive Left Atrial Fibrosis as the Initial Presentation of MYH7 Gene Mutation. JACC Clin. Electrophysiol. 2018, 4, 1488-1490. [CrossRef]

58. Orr, N.; Arnaout, R.; Gula, L.J.; Spears, D.; Leong-Sit, P.; Li, Q.; Tarhuni, W.; Reischauer, S.; Chauhan, V.S.; Borkovich, M.; et al. A mutation in the atrial-specific myosin light chain gene (MYL4) causes familial atrial fibrillation. Nat. Commun. 2016, 7, 11303. [CrossRef]

59. Gudbjartsson, D.F.; Helgason, H.; Gudjonsson, S.A.; Zink, F.; Oddsson, A.; Gylfason, A.; Besenbacher, S.; Magnusson, G.; Halldórsson, B.; Hjartarson, E.; et al. Large-scale whole-genome sequencing of the Icelandic population. Nat. Genet. 2015, 47, 435-444. [CrossRef]

60. Noureldin, M.; Chen, H.; Bai, D. Functional Characterization of Novel Atrial Fibrillation-Linked GJA5 (Cx40) Mutants. Int. J. Mol. Sci. 2018, 19, 977. [CrossRef]

61. Lübkemeier, I.; Andrié, R.; Lickfett, L.; Bosen, F.; Stöckigt, F.; Dobrowolski, R.; Draffehn, A.M.; Fregeac, J.; Schultze, J.L.; Bukauskas, F.F.; et al. The Connexin40A96S mutation from a patient with atrial fibrillation causes decreased atrial conduction velocities and sustained episodes of induced atrial fibrillation in mice. J. Mol. Cell. Cardiol. 2013, 65, 19-32. [CrossRef] [PubMed]

62. Thibodeau, I.L.; Xu, J.; Li, Q.; Liu, G.; Lam, K.; Veinot, J.P.; Birnie, D.H.; Jones, D.L.; Krahn, A.D.; Lemery, R.; et al. Paradigm of Genetic Mosaicism and Lone Atrial Fibrillation. Circulation 2010, 122, 236-244. [CrossRef] [PubMed]

63. Beavers, D.L.; Wang, W.; Ather, S.; Voigt, N.; Garbino, A.; Dixit, S.S.; Landstrom, A.; Li, N.; Wang, Q.; Olivotto, I.; et al. Mutation E169K in Junctophilin-2 Causes Atrial Fibrillation Due to Impaired RyR2 Stabilization. J. Am. Coll. Cardiol. 2013, 62, 2010-2019. [CrossRef] [PubMed]

64. Zhang, X.; Chen, S.; Yoo, S.; Chakrabarti, S.; Zhang, T.; Ke, T.; Oberti, C.; Yong, S.L.; Fang, F.; Li, L.; et al. Mutation in Nuclear Pore Component NUP155 Leads to Atrial Fibrillation and Early Sudden Cardiac Death. Cell 2008, 135, 1017-1027. [CrossRef] [PubMed]

65. Tsai, C.-T.; Hsieh, C.-S.; Chang, S.-N.; Chuang, E.Y.; Juang, J.-M.J.; Lin, L.-Y.; Lai, L.-P.; Hwang, J.-J.; Chiang, F.-T.; Lin, J.-L. Next-generation sequencing of nine atrial fibrillation candidate genes identified novel de novo mutations in patients with extreme trait of atrial fibrillation. J. Med. Genet. 2014, 52, 28-36. [CrossRef] [PubMed]

66. Tucker, N.R.; McLellan, M.A.; Hu, D.; Ye, J.; Parsons, V.A.; Mills, R.W.; Clauss, S.; Dolmatova, E.; Shea, M.A.; Milan, D.J.; et al. Novel Mutation in FLNC (Filamin C) Causes Familial Restrictive Cardiomyopathy. Circ. Cardiovasc. Genet. 2017, 10. [CrossRef] [PubMed]

67. Hein, S.; Kostin, S.; Heling, A.; Maeno, Y.; Schaper, J. The role of the cytoskeleton in heart failure. Cardiovasc. Res. 2000, 45, 273-278. [CrossRef]

68. Knöll, R.; Buyandelger, B. Z-disc Transcriptional Coupling, Sarcomeroptosis and Mechanopoptosis. Cell Biochem. Biophys. 2012, 66, 65-71. [CrossRef]

69. Gerbino, A.; Procino, G.; Svelto, M.; Carmosino, M. Role of Lamin A/C Gene Mutations in the Signaling Defects Leading to Cardiomyopathies. Front. Physiol. 2018, 9, 1356. [CrossRef] [PubMed]

70. Mavroidis, M.; Athanasiadis, N.C.; Rigas, P.S.; Kostavasili, I.; Kloukina, I.; Rijdt, W.P.T.; Kavantzas, N.; Chaniotis, D.; Van Tintelen, J.P.; Skaliora, I.; et al. Desmin is essential for the structure and function of the sinoatrial node: Implications for increased arrhythmogenesis. Am. J. Physiol. Circ. Physiol. 2020, 319, H557-H570. [CrossRef] [PubMed]

71. Brodehl, A.; Pour Hakimi, S.A.; Stanasiuk, C.; Ratnavadivel, S.; Hendig, D.; Gaertner, A.; Gerull, B.; Gummert, J.; Paluszkiewicz, L.; Milting, H. Restrictive Cardiomyopathy is Caused by a Novel Homozygous Desmin (DES) Mutation p.Y122H Leading to a Severe Filament Assembly Defect. Genes 2019, 10, 918. [CrossRef] [PubMed] 
72. Brodehl, A.; Dieding, M.; Klauke, B.; Dec, E.; Madaan, S.; Huang, T.; Gargus, J.; Fatima, A.; Šaric, T.; Cakar, H.; et al. The Novel Desmin Mutant p.A120D Impairs Filament Formation, Prevents Intercalated Disk Localization, and Causes Sudden Cardiac Death. Circ. Cardiovasc. Genet. 2013, 6, 615-623. [CrossRef] [PubMed]

73. Bär, H.; Schopferer, M.; Sharma, S.; Hochstein, B.; Mücke, N.; Herrmann, H.; Willenbacher, N. Mutations in Desmin's CarboxyTerminal "Tail" Domain Severely Modify Filament and Network Mechanics. J. Mol. Biol. 2010, 397, 1188-1198. [CrossRef] [PubMed]

74. Kreplak, L.; Bär, H. Severe Myopathy Mutations Modify the Nanomechanics of Desmin Intermediate Filaments. J. Mol. Biol. 2009, 385, 1043-1051. [CrossRef]

75. Alam, S.; Abdullah, C.S.; Aishwarya, R.; Morshed, M.; Nitu, S.S.; Miriyala, S.; Panchatcharam, M.; Kevil, C.G.; Orr, A.W.; Bhuiyan, S. Dysfunctional Mitochondrial Dynamic and Oxidative Phosphorylation Precedes Cardiac Dysfunction in R120G- $\alpha$ B-CrystallinInduced Desmin-Related Cardiomyopathy. J. Am. Hear. Assoc. 2020, 9, e017195. [CrossRef]

76. Smolina, N.; Khudiakov, A.; Knyazeva, A.; Zlotina, A.; Sukhareva, K.; Kondratov, K.; Gogvadze, V.; Zhivotovsky, B.; Sejersen, T.; Kostareva, A. Desmin mutations result in mitochondrial dysfunction regardless of their aggregation properties. Biochim. Biophys. Acta (BBA)—Mol. Basis Dis. 2020, 1866, 165745. [CrossRef]

77. Galata, Z.; Kloukina, I.; Kostavasili, I.; Varela, A.; Davos, C.; Makridakis, M.; Bonne, G.; Capetanaki, Y. Amelioration of desmin network defects by $\alpha \mathrm{B}$-crystallin overexpression confers cardioprotection in a mouse model of dilated cardiomyopathy caused by LMNA gene mutation. J. Mol. Cell. Cardiol. 2018, 125, 73-86. [CrossRef]

78. Heffler, J.; Shah, P.P.; Robison, P.; Phyo, S.; Veliz, K.; Uchida, K.; Bogush, A.; Rhoades, J.; Jain, R.; Prosser, B.L. A Balance Between Intermediate Filaments and Microtubules Maintains Nuclear Architecture in the Cardiomyocyte. Circ. Res. 2020, 126. [CrossRef]

79. A Dittmer, T.; Misteli, T. The lamin protein family. Genome Biol. 2011, 12, 222. [CrossRef]

80. Captur, G.; Arbustini, E.; Bonne, G.; Syrris, P.; Mills, K.; Wahbi, K.; Mohiddin, S.A.; McKenna, W.J.; Pettit, S.; Ho, C.Y.; et al. Lamin and the heart. Heart 2017, 104, 468-479. [CrossRef]

81. Shemer, Y.; Mekies, L.N.; Ben Jehuda, R.; Baskin, P.; Shulman, R.; Eisen, B.; Regev, D.; Arbustini, E.; Gerull, B.; Gherghiceanu, M.; et al. Investigating LMNA-Related Dilated Cardiomyopathy Using Human Induced Pluripotent Stem Cell-Derived Cardiomyocytes. Int. J. Mol. Sci. 2021, 22, 7874. [CrossRef] [PubMed]

82. Markandeya, Y.S.; Tsubouchi, T.; Hacker, T.A.; Wolff, M.R.; Belardinelli, L.; Balijepalli, R.C. Inhibition of late sodium current attenuates ionic arrhythmia mechanism in ventricular myocytes expressing LaminA-N195K mutation. Heart Rhythm. 2016, 13, 2228-2236. [CrossRef] [PubMed]

83. Chatzifrangkeskou, M.; Yadin, D.; Marais, T.; Chardonnet, S.; Cohen-Tannoudji, M.; Mougenot, N.; Schmitt, A.; Crasto, S.; Di Pasquale, E.; Macquart, C.; et al. Cofilin-1 phosphorylation catalyzed by ERK1/2 alters cardiac actin dynamics in dilated cardiomyopathy caused by lamin A/C gene mutation. Hum. Mol. Genet. 2018, 27, 3060-3078. [CrossRef] [PubMed]

84. Lee, J.; Termglinchan, V.; Diecke, S.; Itzhaki, I.; Lam, C.K.; Garg, P.; Lau, E.; Greenhaw, M.; Seeger, T.; Wu, H.; et al. Activation of PDGF pathway links LMNA mutation to dilated cardiomyopathy. Nature 2019, 572, 335-340. [CrossRef] [PubMed]

85. Pickersgill, H.; Kalverda, B.; de Wit, E.; Talhout, W.; Fornerod, M.; Van Steensel, B. Characterization of the Drosophila melanogaster genome at the nuclear lamina. Nat. Genet. 2006, 38, 1005-1014. [CrossRef] [PubMed]

86. Salvarani, N.; Crasto, S.; Miragoli, M.; Bertero, A.; Paulis, M.; Kunderfranco, P.; Serio, S.; Forni, A.; Lucarelli, C.; Ferro, M.D.; et al The K219T-Lamin mutation induces conduction defects through epigenetic inhibition of SCN5A in human cardiac laminopathy. Nat. Commun. 2019, 10, 1-16. [CrossRef]

87. Chen, S.N.; Lombardi, R.; Karmouch, J.; Tsai, J.-Y.; Czernuszewicz, G.Z.; Taylor, M.R.; Mestroni, L.; Coarfa, C.; Gurha, P.; Marian, A.J.; et al. DNA Damage Response/TP53 Pathway Is Activated and Contributes to the Pathogenesis of Dilated Cardiomyopathy Associated With LMNA (Lamin A/C) Mutations. Circ. Res. 2019, 124, 856-873. [CrossRef]

88. Diguet, N.; Trammell, S.A.J.; Tannous, C.; Deloux, R.; Piquereau, J.; Mougenot, N.; Gouge, A.; Gressette, M.; Manoury, B.; Blanc, J.; et al. Nicotinamide Riboside Preserves Cardiac Function in a Mouse Model of Dilated Cardiomyopathy. Circulation 2018, 137, 2256-2273. [CrossRef]

89. Murata, M.M.; Kong, X.; Moncada, E.; Chen, Y.; Imamura, H.; Wang, P.; Berns, M.; Yokomori, K.; Digman, M.A. NAD+ consumption by PARP1 in response to DNA damage triggers metabolic shift critical for damaged cell survival. Mol. Biol. Cell 2019, 30, 2584-2597. [CrossRef]

90. Zhang, D.; Hu, X.; Li, J.; Liu, J.; Bulte, L.B.-T.; Wiersma, M.; Malik, N.-U.; Van Marion, D.M.S.; Tolouee, M.; Hoogstra-Berends, F.; et al. DNA damage-induced PARP1 activation confers cardiomyocyte dysfunction through NAD+ depletion in experimental atrial fibrillation. Nat. Commun. 2019, 10, 1-17. [CrossRef]

91. Ramos, K.S.; Brundel, B.J.J.M. DNA Damage, an Innocent Bystander in Atrial Fibrillation and Other Cardiovascular Diseases? Front. Cardiovasc. Med. 2020, 7, 67. [CrossRef] [PubMed]

92. Nikolova, V.; Leimena, C.; McMahon, A.C.; Tan, J.C.; Chandar, S.; Jogia, D.; Kesteven, S.H.; Michalicek, J.; Otway, R.; Verheyen, F.; et al. Defects in nuclear structure and function promote dilated cardiomyopathy in lamin A/C-deficient mice. J. Clin. Investig. 2004, 113, 357-369. [CrossRef] [PubMed]

93. Swift, J.; Ivanovska, I.L.; Buxboim, A.; Harada, T.; Dingal, P.C.D.P.; Pinter, J.; Pajerowski, J.D.; Spinler, K.R.; Shin, J.-W.; Tewari, M.; et al. Nuclear Lamin-A Scales with Tissue Stiffness and Enhances Matrix-Directed Differentiation. Science 2013, 341, 1240104. [CrossRef] [PubMed] 
94. Buxboim, A.; Swift, J.; Irianto, J.; Spinler, K.R.; Dingal, P.C.D.P.; Athirasala, A.; Kao, Y.-R.C.; Cho, S.; Harada, T.; Shin, J.-W.; et al. Matrix Elasticity Regulates Lamin-A,C Phosphorylation and Turnover with Feedback to Actomyosin. Curr. Biol. 2014, 24, 1909-1917. [CrossRef] [PubMed]

95. Guilluy, C.; Osborne, L.D.; Van Landeghem, L.; Sharek, L.; Superfine, R.; Garcia-Mata, R.; Burridge, K. Isolated nuclei adapt to force and reveal a mechanotransduction pathway in the nucleus. Nat. Cell Biol. 2014, 16, 376-381. [CrossRef]

96. Chai, R.J.; Werner, H.; Li, P.Y.; Lee, Y.L.; Nyein, K.T.; Solovei, I.; Luu, T.D.A.; Sharma, B.; Navasankari, R.; Maric, M.; et al. Disrupting the LINC complex by AAV mediated gene transduction prevents progression of Lamin induced cardiomyopathy. Nat. Commun. 2021, 12,1-16. [CrossRef]

97. Liu, H.-T.; Ji, F.-F.; Wei, L.; Zuo, A.-J.; Gao, Y.-X.; Qi, L.; Jin, B.; Wang, N.-N.; Zhao, P. Screening of MYH7 gene mutation sites in hypertrophic cardiomyopathy and its significance. Chin. Med. J. 2019, 132, 2835-2841. [CrossRef]

98. Waldmüller, S.; Erdmann, J.; Binner, P.; Gelbrich, G.; Pankuweit, S.; Geier, C.; Timmermann, B.; Haremza, J.; Perrot, A.; Scheer, S.; et al. Novel correlations between the genotype and the phenotype of hypertrophic and dilated cardiomyopathy: Results from the German Competence Network Heart Failure. Eur. J. Hear. Fail. 2011, 13, 1185-1192. [CrossRef]

99. Holm, H.; Gudbjartsson, D.F.; Sulem, P.; Masson, G.; Helgadottir, H.T.; Zanon, C.; Magnusson, O.T.; Helgason, A.; Saemundsdottir, J.; Gylfason, A.; et al. A rare variant in MYH6 is associated with high risk of sick sinus syndrome. Nat. Genet. 2011, 43, 316-320. [CrossRef]

100. Li, S.; Jiang, Z.; Wen, L.; Feng, G.; Zhong, G. MicroRNA-208a-3p contributes to connexin40 remolding in human chronic atrial fibrillation. Exp. Ther. Med. 2017, 14, 5355-5362. [CrossRef]

101. Sarantis, P.; Gaitanaki, C.; Beis, D. Ventricular remodeling of single-chambered myh6 ${ }^{-/-}$adult zebrafish hearts occurs via a hyperplastic response and is accompanied by elastin deposition in the atrium. Cell Tissue Res. 2019, 378, 279-288. [CrossRef] [PubMed]

102. Ishikawa, T.; Jou, C.J.; Nogami, A.; Kowase, S.; Arrington, C.B.; Barnett, S.M.; Harrell, D.T.; Arimura, T.; Tsuji, Y.; Kimura, A.; et al. Novel Mutation in the $\alpha$-Myosin Heavy Chain Gene Is Associated With Sick Sinus Syndrome. Circ. Arrhythmia Electrophysiol. 2015, 8, 400-408. [CrossRef] [PubMed]

103. Srinivas, M.; Verselis, V.K.; White, T.W. Human diseases associated with connexin mutations. Biochim. Biophys. Acta (BBA)Biomembr. 2018, 1860, 192-201. [CrossRef] [PubMed]

104. Rodríguez-Sinovas, A.; Sánchez, J.; Valls-Lacalle, L.; Consegal, M.; Ferreira-González, I. Connexins in the Heart: Regulation, Function and Involvement in Cardiac Disease. Int. J. Mol. Sci. 2021, 22, 4413. [CrossRef] [PubMed]

105. Nattel, S.; Heijman, J.; Zhou, L.; Dobrev, D. Molecular Basis of Atrial Fibrillation Pathophysiology and Therapy: A Translational Perspective. Circ. Res. 2020, 127, 51-72. [CrossRef] [PubMed]

106. Borin, D.; Peña, B.; Chen, S.N.; Long, C.S.; Taylor, M.R.; Mestroni, L.; Sbaizero, O. Altered microtubule structure, hemichannel localization and beating activity in cardiomyocytes expressing pathologic nuclear lamin A/C. Heliyon 2020, 6, e03175. [CrossRef]

107. Mounkes, L.C.; Kozlov, S.V.; Rottman, J.N.; Stewart, C.L. Expression of an LMNA-N195K variant of A-type lamins results in cardiac conduction defects and death in mice. Hum. Mol. Genet. 2005, 14, 2167-2180. [CrossRef]

108. Herrmann, H.; Cabet, E.; Chevalier, N.R.; Moosmann, J.; Schultheis, D.; Haas, J.; Schowalter, M.; Berwanger, C.; Weyerer, V.; Agaimy, A.; et al. Dual Functional States of R406W-Desmin Assembly Complexes Cause Cardiomyopathy With Severe Intercalated Disc Derangement in Humans and in Knock-In Mice. Circulation 2020, 142, 2155-2171. [CrossRef]

109. Gemel, J.; Levy, A.E.; Simon, A.R.; Bennett, K.B.; Ai, X.; Akhter, S.; Beyer, E.C. Connexin40 abnormalities and atrial fibrillation in the human heart. J. Mol. Cell. Cardiol. 2014, 76, 159-168. [CrossRef]

110. Wirka, R.C.; Gore, S.; Van Wagoner, D.R.; Arking, D.E.; Lubitz, S.A.; Lunetta, K.; Benjamin, E.; Alonso, A.; Ellinor, P.; Barnard, J.; et al. A Common Connexin-40 Gene Promoter Variant Affects Connexin-40 Expression in Human Atria and Is Associated With Atrial Fibrillation. Circ. Arrhythmia Electrophysiol. 2011, 4, 87-93. [CrossRef]

111. Bai, D. Atrial fibrillation-linkedGJA5/connexin 40 mutants impaired gap junctions via different mechanisms. FEBS Lett. 2014, 588, 1238-1243. [CrossRef] [PubMed]

112. Sun, Y.; Hills, M.D.; Ye, W.G.; Tong, X.; Bai, D. Atrial Fibrillation-Linked Germline GJA5/Connexin40 Mutants Showed an Increased Hemichannel Function. PLoS ONE 2014, 9, e95125. [CrossRef] [PubMed]

113. Cruz, A.S.; Meşe, G.; Valiuniene, L.; Brink, P.R.; White, T.W.; Valiunas, V. Altered conductance and permeability of Cx40 mutations associated with atrial fibrillation. J. Gen. Physiol. 2015, 146, 387-398. [CrossRef] [PubMed]

114. Poulet, C.; Sanchez-Alonso, J.; Swiatlowska, P.; Mouy, F.; Lucarelli, C.; Alvarez-Laviada, A.; Gross, P.; Terracciano, C.; Houser, S.; Gorelik, J. Junctophilin-2 tethers T-tubules and recruits functional L-type calcium channels to lipid rafts in adult cardiomyocytes. Cardiovasc. Res. 2020, 117, 149-161. [CrossRef] [PubMed]

115. Brandenburg, S.; Pawlowitz, J.; Eikenbusch, B.; Peper, J.; Kohl, T.; Mitronova, G.Y.; Sossalla, S.; Hasenfuss, G.; Wehrens, X.H.; Kohl, P.; et al. Junctophilin-2 expression rescues atrial dysfunction through polyadic junctional membrane complex biogenesis. JCI Insight 2019, 4, 12. [CrossRef]

116. Burdine, R.D.; Preston, C.C.; Leonard, R.J.; Bradley, T.A.; Faustino, R.S. Nucleoporins in cardiovascular disease. J. Mol. Cell. Cardiol. 2020, 141, 43-52. [CrossRef]

117. Knockenhauer, K.E.; Schwartz, T.U. The Nuclear Pore Complex as a Flexible and Dynamic Gate. Cell 2016, $164,1162-1171$. [CrossRef]

118. Goldberg, M.W. Nuclear pore complex tethers to the cytoskeleton. Semin. Cell Dev. Biol. 2017, 68, 52-58. [CrossRef] 
119. Donnaloja, F.; Jacchetti, E.; Soncini, M.; Raimondi, M.T. Mechanosensing at the Nuclear Envelope by Nuclear Pore Complex Stretch Activation and Its Effect in Physiology and Pathology. Front. Physiol. 2019, 10, 896. [CrossRef]

120. Tarazón, E.; Rivera, M.; Roselló-Lletí, E.; Molina-Navarro, M.M.; Sánchez-Lázaro, I.J.; España, F.; Montero, J.A.; Lago, F.; Juanatey, J.R.G.; Portolés, M. Heart Failure Induces Significant Changes in Nuclear Pore Complex of Human Cardiomyocytes. PLoS ONE 2012, 7, e48957. [CrossRef]

121. Nanni, S.; Re, A.; Ripoli, C.; Gowran, A.; Nigro, P.; D’Amario, D.; Amodeo, A.; Crea, F.; Grassi, C.; Pontecorvi, A.; et al. The nuclear pore protein Nup153 associates with chromatin and regulates cardiac gene expression in dystrophicmdxhearts. Cardiovasc. Res. 2016, 112, 555-567. [CrossRef] [PubMed]

122. Oberti, C.; Wang, L.; Li, L.; Dong, J.; Rao, S.; Du, W.; Wang, Q. Genome-Wide Linkage Scan Identifies a Novel Genetic Locus on Chromosome 5p13 for Neonatal Atrial Fibrillation Associated with Sudden Death and Variable Cardiomyopathy. Circulation 2004, 110, 3753-3759. [CrossRef] [PubMed]

123. Preston, C.C.; Wyles, S.P.; Reyes, S.; Storm, E.C.; Eckloff, B.W.; Faustino, R.S. NUP155 insufficiency recalibrates a pluripotent transcriptome with network remodeling of a cardiogenic signaling module. BMC Syst. Biol. 2018, 12, 62. [CrossRef] [PubMed]

124. Zhou, C.; Rao, L.; Shanahan, C.M.; Zhang, Q. Nesprin-1/2: Roles in nuclear envelope organisation, myogenesis and muscle disease. Biochem. Soc. Trans. 2018, 46, 311-320. [CrossRef] [PubMed]

125. Zhang, Q.; Bethmann, C.; Worth, N.F.; Davies, J.D.; Wasner, C.; Feuer, A.; Ragnauth, C.D.; Yi, Q.; Mellad, J.A.; Warren, D.T.; et al. Nesprin-1 and -2 are involved in the pathogenesis of Emery-Dreifuss muscular dystrophy and are critical for nuclear envelope integrity. Hum. Mol. Genet. 2007, 16, 2816-2833. [CrossRef] [PubMed]

126. Banerjee, I.; Zhang, J.; Moore-Morris, T.; Pfeiffer, E.; Buchholz, K.S.; Liu, A.; Ouyang, K.; Stroud, M.J.; Gerace, L.; Evans, S.M.; et al. Targeted Ablation of Nesprin 1 and Nesprin 2 from Murine Myocardium Results in Cardiomyopathy, Altered Nuclear Morphology and Inhibition of the Biomechanical Gene Response. PLoS Genet. 2014, 10, e1004114. [CrossRef] [PubMed]

127. Mao, Z.; Nakamura, F. Structure and Function of Filamin C in the Muscle Z-Disc. Int. J. Mol. Sci. 2020, 21, 2696. [CrossRef]

128. Song, S.; Shi, A.; Lian, H.; Hu, S.; Nie, Y. Filamin C in cardiomyopathy: From physiological roles to DNA variants. Hear. Fail. Rev. 2021, 1-13. [CrossRef] 